\title{
ANALISIS PERBEDAAN PERILAKU IMPULSE BUYING BERDASARKAN GENDER PADA MARKETPLACE TOKOPEDIA
}

\author{
R.A.Nurlinda, Aisyah Yuliyani \\ Fakultas Ekonomi dan Bisnis, Universitas Esa Unggul \\ Jalan Arjuna Utara No 9 Kebon Jeruk Jakarta 11510 \\ nurlinda@esaunggul.ac.id
}

\begin{abstract}
Unplanned buying behavior or impulsive buying from consumers is something that is interesting, because it is the largest market share in today's modern market and one of the important causes of Impulse buying behavior is gender. This study aims to determine whether there are differences in Impulse buying between men and women and to determine whether the Shopping Lifestyle, Fashion Involvement, Situational Factors, and Positive Emotion variables cause differences in Impulse buying between men and women. The sample used was 140 respondents, each 70 male respondents and 70 female respondents with purposive sampling technique. The method used in this research is discriminant analysis by first doing the validity and reliability test. The results of this study indicate that there are differences between men and women in Impulse buying in Tokopedia, from these results it is also known that the variables that distinguish male and female Impulse buying are fashion infolvement, Situational Factors and Positive Emotion and situational factors are the most dominant variables distinguishing Impulse buying men and women. The results of this study are expected to help all parties engaged in or associated with e-commerce in improving the quality of their services so that they can provide convenience for third consumers shopping online.
\end{abstract}

Keywords: Impulse buying, Gender, Shopping Lifestyle

\begin{abstract}
Abstrak
Perilaku pembelian yang tidak direncanakan atau pembelian impulsif dari konsumen merupakan sesuatu yang menarik, karena merupakan pangsa pasar terbesar dalam pasar modern saat ini dan salah satu yang menjadi penyebab penting terjadinya perilaku Impulse buying adalah jenis kelamin. Penelitian ini bertujuan untuk mengetahui apakah terdapat perbedaan Impulse buying antara pria dan wanita serta mengetahui apakah variabel Shopping Lifestyle, Fashion Involvement, Faktor Situasional, dan Positive Emotion yang menyebabkan perbedaan Impulse buying pada pria dan wanita. Sampel yang digunkan sebanyak 140 responden, masing-masing 70 responden pria dan 70 responden wanita dengan teknik purposive sampling. Metode yang digunakan dalam penelitian ini adalah analisis diskriminan dengan terlebih dahulu melakukan uji validiats dan reliabilitas. Hasil penelitian ini menunjukan bahwa terdapat perbedaan antara pria dan wanita dalam Impulse buying di Tokopedia, dari hasil tersebut juga diketahui bahwa Variabel yang membedakan Impulse buying pria dan wanita adalah fashion infolvement, Faktor Situasional dan Positive Emotion dan Faktor situasional merupakan variabel yang paling dominan membedakan Impulse buying pria dan wanita. Hasil penelitian ini diharapkan dapat membantu segala pihak yang bergerak atau berhubungan dengan e-commerce dalam meningkatkan kualitas pelayanannya sehingga dapat memberikan kenyamanan bagi konsumen ketiga berbelanja online
\end{abstract}

Kata Kunci : Impulse buying, Jenis Kelamin, Shopping Lifestyle

\section{Pendahuluan}

Pada saat ini perilaku berbelanja online sudah menjadi kebiasaan masyarakat Indonesia, Menurut data Wearesocial dan Hootsuite, sekitar $90 \%$ pengguna internet di Indonesia pernah berbelanja online. Belanja online merupakan proses ketika consumer membeli barang atau jasa dari penjual secara real time melalui jejaring internet (Zhang, Xu, Zhao, \& $\mathrm{Yu}, 2018$ ). Dengan perkembangan bisnis saat ini munculnya electronic commerce atau biasa disebut dengan e-commerce sebagai wadah 
para pembinis untuk memulai proses perdagangan (pembelian, penjualan, pertukaran produk, jasa atau informasi) yang dilakukan melalui perangkat mobile atau komputer yang terhubunga dengan internet.

E-commerce hadir untuk mempermudah penjual maupun pembeli untuk melakukan transaksi jual beli produk maupun jasa tanpa harus melakukan tatap muka secara langsung. Demikan pula Tokopedia.com yang merupakan toko online pertama di Indonesia. Marketplace Tokopedia menyediakan peluang bisnis dan menjual berbagai jenis produk dengan harga yang lebih terjangkau dibandingkan toko umumnya. Dalam upaya memberikan kenyamana kepada konsumen saat berbelaja, Tokopedia menyediakan mesin pencari (search engine) yang memudahkan konsumen dalam pencarian produk, dan fitur direktori yang dimanfaatkan sebagai katalog belanja. Tokopedia menduduki urutan pertama sejak 2018 hingga 2019 dikarenakan ada 168 juta kunjungan yang hampir meningkat $10 \%$ dari kuartal sebelumnya.

Perilaku pembelian Konsumen di Indonesia yang menunjukan bahwa kebanyakan segmen anak muda yeng sering melakukan Impulse buying bahkan tergolong impulsif. Adanya Impulse buying menjadikan toko online di Indonesia menawarkan berbagai keunggulan dalam menyediakan pelayanan yang menarik Konsumen dan dapat berbelanja dengan leluasa, berikut merupakan tabel persaingan toko online di Indonesia. Konsumen lebih suka menghabiskan waktu mereka untuk berbelanja (shopping), bersosialisasi satu sama lain dan memenuhi semua keinginan mereka sehingga ini bisa mengarah pada pembelian impulsif (Hursepuny \& Oktafani, 2018). Liantifa \& Siswadhi, (2019), Maulana \& Novalia (2019) menyatakan bahwa Shopping Lifestyle berpengaruh positif dan signifikan terhadap Impulse buying. Seseorang yang sudah mengikuti perkembangan gaya hidup seperti dengan fashion, rela menghabiskan waktu untuk mengikuti trend terbaru, di mana dalam penelitian Tawas \& Mandey (2014) menyatakan fashion involvement berpengaruh terhadap perilaku Impulse buying dikarenakan adanya keterkaitan pada e-commerce dan perlu meningkatkan fashion involvement yaitu dengan memperbesar ketertarikan pelanggan pada produk kategori fashion dari dalam negeri maupun luar negeri yang terkenal dengan kualitas dengan harga yang terjangkau. Menurut Widiartaka \& Purnami (2014) lingkungan toko memiliki pengaruh yang signifikan pada kondisi emosional, termasuk kesenangan dan gairah, yang pada akhirnya akan mempengaruhi consumer untuk membeli secara impulse saat berada di e-commerce.

Beberapa literatur yang meneliti pembelian impulsif menunjukkan bahwa ada hubungan antara gender dan Impulse buying bahavior (Tifferet \& Herstein, 2012), lebih spesifik lagi menurut Purwanto \& Wijaya (2018) mengatakan beda gender umumnya akan memiliki kecenderungan yang berbeda, sedangkan Aprilianty, F \& Purwanegara, (2015). menunjukan bahwa consumer wanita yang berusia 18-24 tahun memiliki kecenderungan tinggi untuk melakukan pembelian secara impulsif. Berdasarkan latar belakang yang telah diuraikan diatas, maka penelitian ini bertujuan (1) untuk mengetahui perbedaan dalam Impulse buying antara pria dan wanita di Tokopedia, (2) untuk mengetahui manakah dari variabel shopping lifestyle, fashion involvement, faktor situasional dan positive emotion yang menyebabkan perbedaan Impulse buying pada pria dan wanita di Tokopedia.

\section{Impulse buying}

Impulse buying adalah perilaku berbelanja seseorang yang terjadi secara cepat (Setyningrum, Arifin, \& Yulianto, 2016) Impulse buying adalah aspek perilaku konsumen yang meresap dan salah satu pertimbangan utama untuk aktivitas untuk aktivitas pemasaran karena kerumintan dan luasnya kejadian impulse buying di berbagai jenis produ(Chang, Yan, \& Eckman, 2014). Ketika calon konsumen melihat lebih banyak pembeli pada sebuah toko, makan akan mendesak mereka melakukan pembelian impulsif (Chan, Cheung, \& Lee, 2017). Menurut In'am, Suharyono, \& Yulianto (2016) pembelian spontan atau Impulse buying merupakan keputusan pembelian yang dibuat oleh pelanggan secara spontan atau seketika saat melihat sebuah produk. Keputusan pembelian merupakan suatu proses pembelian berkaitan dengan keputusan merek, penjualan, waktu 
pembelian, dan cara pembayaran (Limento \& Cahyadi, 2020). Impulsif merupakan bagian dari perilaku konsumen terhadap sebuah keputusan pembelian, dimana pembelian tersebut dilakukan secara tidak terenca yang disebabkan oleh berbagai faktor.

\section{Shopping Lifestyle}

Shopping Lifestyle dapat diartikan sebagai perilaku yang ditunjukkan oleh pelanggan sehubungan dengan serangkaian tanggapan dan pendapat pribadi tentang pembelian produk (Tirmizi, Kashif-Ur-Rehman, \& Saif, 2009). Menurut Zablocki dan Kanter dalam Japarianto \& Sugiharto (2012). Cara kita berbelanja mencerminkan status, martabat dan kebiasaan. Shopping Lifestyle menunjukkan cara seseorang memilih untuk mengalokasikan pendapatan, baik dari segi alokasi dana untuk berbagai produk dan layanan, maupun alternatif tertentu dalam membedakan kategori yang serupa Shopping lifestyle menurut Darma \& Japarianto (2014) digambarkan dengan dimensi sebagai berikut: Kegiatan (Activities), Minat (Interest) dan Opini (Opinion)

\section{Fashion Involvement}

Menurut Fauziyyah \& Oktafani (2018) mendefinisikan keterlibatan sebagai tingkat kepentingan pribadi yang dirasakan atau minat yang dibangkitkan oleh stimulus di dalam situasi tertentu. Fashion involvement adalah tingkat ketertarikan yang di wujudkan dari tingkat keterlibatan berbagai hal yang berhubungan dengan pakaian atau perlengkapan yang fashionable (Tirmizi et al., 2009). Fashion involvement memiliki 5 dimensi utama yang dikonseptualisasikan dari tingkat kesadaran rendah hingga tinggi menurut Natalie A. \& Japarianto (2019). 5 Dimensi tersebut adalah Fashion innovativeness and time of purchase, Fashion interpersonal communication, Fashion interest, Fashion eligibility, Fashion awareness dan reaction to fashion trend,

\section{Faktor Situasional}

Menurut Rizki (2016) faktor situasional adalah eksternal yang datang dari lingkungan toko online saat konsumen merasakan stimuli visual tertentu (produk atau promosi) yang menciptakan pembelian pada toko online.
Faktor situasional merupakan semua faktorfaktor tertentu untuk waktu dan tempat yang tidak diikuti dari pengetahuan tentang sifat stabil dari konsumen dan stimulus, dan yang memiliki pengaruh perilaku saat terjadi (Mothersbaugh \& Hawkins, 2016). Terdapat variabel yang diukur dengan tujuh indikator, yaitu: Design website di toko online menarik, Penjual ditoko online memberikan respon yang cepat, Display (tampilan) tentang produk di toko online jelas, Produk di toko online mudah untuk ditemukan, Konsumen sering menyarankan untuk berbelanja di toko online, Produk yang dibeli di toko online adalah produk yang sudah terkenal dan Toko online sering melakukan kegiatan promosi.

\section{Positive Emotion}

Menurut Dewi (2015), Marianty (2012) dan Andriyanto, Suyadi, \& Fanani (2016) Emosi positif adalah emosi yang mampu menghadirkan perasaan positif terhadap seseorang yang mengalaminya. Emosi positif dapat didatangkan dari sebelum terjadinya mood seseorang, kecondongan sifat afektif seseorang dan reaksi pada lingkungan yang mendukung seperti ketertarikan pada item barang, pelayanan yang diberikan ke konsumen, ataupun adanya promosi penjualan. Menurut Darma \& Japarianto (2014) positive emotion dapat diuraikan menjadi 3 dimensi, yaitu: Pleasure, Arousal dan Dominance.

\section{Pengembangan Hipotesis (Kerangka Konseptual)}

Berdasarkan Hasil analisis penelitian yang dilakukan oleh Diba, (2013), Rizki (2016), dan Afandi \& Hartati (2019) menyatakan bahwa hasil analisis yang telah dilakukan diketahui bahwa terdapat perbedaan antara pria dan wanita dalam keputusan pembelian impulsif. Terdapat perbedaan antara remaja putra dan remaja putri dalam kontrol diri. Remaja putri lebih dominan pada pembelian impulsif dan memiliki peranan kontrol diri yang buruk.

H_1: Terdapat perbedaan dalam pembelian impulsif antara pria dan wanita di Tokopedia.

Hasil uji beda yang yang dilakukan Ningrum \& Matulessy (2018) memberikan analisis yang sudah dilakukan dapat diketahui hasil penelitian menemukan bahwa wanita lebih 
impulsif dibandingkan pria. Hal ini dapat disebabkan oleh perbedaan shopping lifestyle antara pria dan wanita. Menurut Pramesti \& Iqbal (2018) hasil penelitian menggunakan uji one wat anova ini menunjukkan bahwa terdapat perbedaan yang signifikan pada Shopping Lifestyle pada Generasi X, Y, Z. Menurut Sultana, (2016) tiga faktor yang mempengaruhi fashion involvement yaitu: matrialism, usia, dan jenis kelamin. Berdasarkan penelitian yang dilakukan Tulungen ( 2013) dan Astari \& Widagda K., (2014) menerangkan bahwa hasil analisis yang telah dilakukan dapat diketahui terdapat berbedaan perbedaan signifikan dengan impuse buying wanita yang lebih tinggi dari pria ketika memiliki faktor situasional menunjukan bahwa rata-rata antara pria dan wanita berbeda.

H_2 :Variabel shopping lifestyle, fashion involvement, faktor situasional dan positive emotion yang menyebabkan perbedaan Impulse buying pada pria dan wanita di Tokopedia.

Berdasarkan kajian pustaka dan pengembangan hipotesis yang telah dijabarkan pada bagian sebelumnya, maka dapat diperoleh model penelitian sebagai berikut:

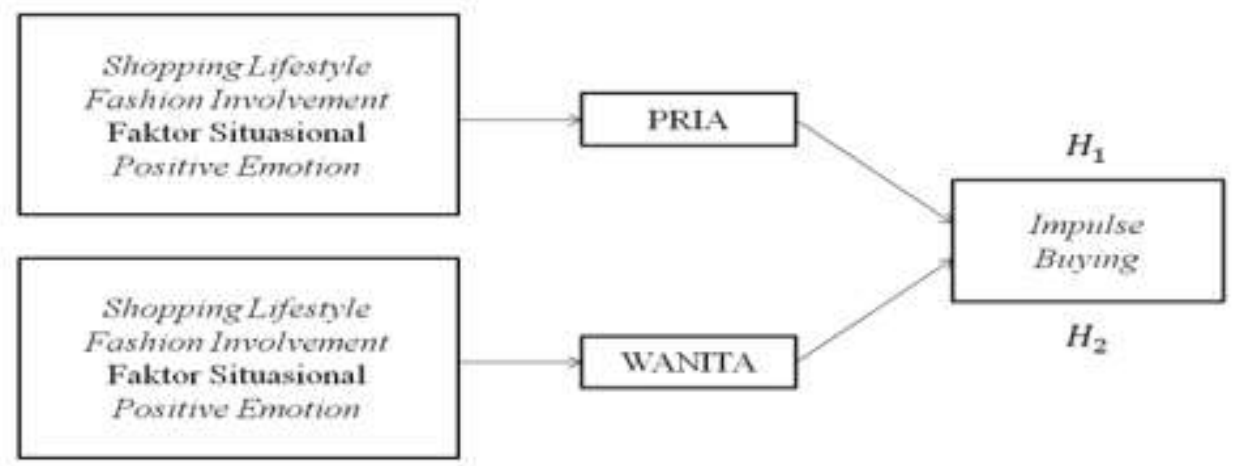

Gambar 1

Model Penelitian

\section{Metode Penelitian}

Penelitian ini dilakukan dengan model pendekatan kuantitatif artinya pengumpulan data yang bertujuan mengembangkan dan menggunakan model-model matematis, teoriteori, dan hipotesis yang dikaitkan dengan fenomena alam. Penelitian kuantitatif biasanya menggunakan desain ekplanasi, dimana objek telahan penelitian eksplanasi (explanatory research) adalah untuk mengetahui adanya perbedaan atau tidak antar variabel yang di hipotesiskan. Pada jenis penelitian ini, jelas ada hipotesis yang di uji kebenarannya

\section{Jenis dan Sumber Data}

Jenis data yang digunakan dalam penelitian ini adalah data kualitatif yang merupakan data yang diperoleh dari responden secara langsung melalui kuesioner, kemudian data tersebut dikuantitatifkan dengan memberikan skor atau angka pada masing-masing jawaban responden. (Sujarweni, 2013) Penelitian ini menggunakan bobot berdasarkan skala likert 14 untuk mendapatkan data yang bersifat interval. Skala likert digunakan untuk mengukur Shopping Lifestyle, Fashion Involvement, Situational Factors, dan Positive Emotion.

Pengukuran dengan skala likert adalah untuk kategori pernyataan dengan jawaban sangat setuju sampai dengan sangat tidak setuju. Data yang digunakan dalam penelitian ini terdiri dari data primer dan data sekunder. Pada penelitian ini data primer yang digunakan merupakan data yang diperoleh melalui hasil penyebaran kuisioner pada sampel yang telah ditentukan berupa data mentah yang berisi tanggapan konsumen tentang Shopping Lifestyle, Fashion Involvement, Situational Factors, dan Positive Emotion. Sedangkan data sekunder dalam penelitian ini diperoleh melalui buku, jurnal, internet dan sumber bacaan lainnya yang berkaitan dengan topik penelitian.

\section{Populasi dan Sampel}

Populasi adalah kelompok elemen yang lengkap, yang biasanya berupa orang, obyek, transaksi, atau kejadian di mana kita tertarik untuk mempelajarinya atau menjadi obyek 
penelitian (Sugiyono, 2017). Populasi dalam penelitian ini adalah keseluruhan konsumen yang pernah membeli di Tokopedia dan pernah melakukan Impulse buying. Jumlah populasi dalam penelitian ini tidak diketahui.

\section{Sampel}

Pengambilan sampel disesuaikan dengan banyaknya jumlah item pertanyaan yang digunakan dalan kuisioner tersebut (Hair, 2010). Dalam penelitian ini jumlah sampel sebanyak 140 orang. Metode pengambilan sampel yang digunakan dalam penelitian ini adalah dengan menggunakan teknik purposive sampling (Sugiyono, 2017), dengan kreteria adalah konsumen yang mempunyai aplikasi Tokopedia, pernah melakukan Impulse buying di Tokopedia 2 bulan terakhir

\section{Teknik Analisis Data}

Uji Validitas

Uji Validitas dugunakan untuk mengukur valid atau tidaknya suatu kuisioner. Suatu kuesioner dikatakan valid jika pertanyaan pada kuesioner mampu mengungkap suatu yang akan diukur oleh kuesioner tersebut. Tujuan dari uji validitas adalah mengetahui ketepatan atas kecermatan suatu intrument pengukuran dalam melakukan fungsi ukurnya supaya data dapat diperoleh secara relavanatau jelas dan sesuai dengan maksud diadakanya pengukuran tersebut. Pernyataan yang dikatakan valid atau dapat diukur adalah: jika signifikan dari korelasi $(r)<0,05$ maka dikatakan valid dan jika signifikan dari korelasi $(r)>0,05$ maka dikatakan tidak valid.

\section{Uji Reliabilitas}

Menurut Sugiyono, (2017) Istrument yang reliabel bila dapat kesamaan data dalam waktu yang berbeda. Suatu nilai yang menunjukan konsistensi suatu alat pengukur di dalam mengukur gejala yang sama. Reliabilitas dinyatakan oleh koefisensi reliabilitas yang angkanya berbeda dalam rentang $0-1$, semakin mendekati angka 1 dan $\geq 0,6$, maka dinyatakan reliabilitas semakin tinggi. Sebaliknya bila semakin 0 (nol) makan reliabilitasnya semakin rendah.
Data yang terkumpul dalam penelitian ini dianalisis dengan Analisis Diskriminan. Pengelompokkan ini bersifat mutually exclusive, dalam artian jika obyek A sudah masuk kelompok 1, maka ia tidak mungkin juga dapat menjadi anggota kelompok 2. Analisis kemudian dapat dikembangkan pada 'variabel mana saja yang membuat kelompok 1 berbeda dengan kelompok 2, berapa persen yang masuk ke kelompok 1 , berapa persen yang masuk ke kelompok 2. Oleh karena ada sejumlah variabel independen, maka akan terdapat satu variabel dependent (tergantung), ciri analisis diskriminan adalah jenis data dari variabel dependent bertipe nominal (kategori), seperti kode 0 dan 1, atau kode 1 , 2 dan 3 serta kombinasi lainnya (Malhotra, 2009).Untuk mempermudah dalam proses perhitungan, maka digunakan alat bantu dengan menggunakan SPSS.

\section{Hasil dan Pembahasan \\ Uji Validitas}

Dari hasil uji validitas, dari 28 pertanyaan terdiri dari 6 pertanyaan tentang Shopping Lifestyle (SP), 10 pertanyaan tentang Fashion Involvement (FI), 7 pertanyaan tentang Faktor Situasional (FS) dan 5 pertanyaan tentang Positive Emotion (PE). Berdasarkan hasil uji validitas terdapat satu pernyataan tidak valid karena memiliki nilai diatas $>0,05$. Sehingga dapat disimpulkan dari 28 pernyataan hanya 27 yang layak digunakan dan dapat mengukur indikator dan variabel dari penelitian ini. Adapaun hasil Ujian Validitas dapat dilihat pada tabel 1 berikut ini: 
Tabel 1

Uji Validitas

\begin{tabular}{|c|c|c|c|c|}
\hline No & Kuesioner & Nilai sig Hitung & Nilai Sig Standar & Keterangan \\
\hline 1 & SP1 & 0,003 & 0,00 & Valid \\
\hline 2 & SP2 & 0,000 & 0,00 & Valid \\
\hline 3 & SP3 & 0,000 & 0,05 & Valid \\
\hline 4 & SP4 & 0,000 & 0,05 & Valid \\
\hline 5 & SP5 & 0,000 & 0,05 & Valid \\
\hline 6 & SP6 & 0,000 & 0,05 & Valid \\
\hline 7 & FI1 & 0,000 & 0,05 & Valid \\
\hline 8 & FI2 & 0,000 & 0,05 & Valid \\
\hline 9 & FI3 & 0,005 & 0,05 & Valid \\
\hline 10 & FI4 & 0,001 & 0,05 & Valid \\
\hline 11 & FI5 & 0,000 & 0,05 & Valid \\
\hline 12 & FI6 & 0,000 & 0,05 & Valid \\
\hline 13 & FI7 & 0,000 & 0,05 & Valid \\
\hline 14 & FI8 & 0,067 & 0,05 & Tidak Valid \\
\hline 15 & FI9 & 0,035 & 0,05 & Valid \\
\hline 16 & FI10 & 0,000 & 0,05 & Valid \\
\hline 17 & FS1 & 0,000 & 0,05 & Valid \\
\hline 18 & FS2 & 0,000 & 0,05 & Valid \\
\hline 19 & FS3 & 0,000 & 0,05 & Valid \\
\hline 20 & FS4 & 0,000 & 0,05 & Valid \\
\hline 21 & FS5 & 0,000 & 0,05 & Valid \\
\hline 22 & FS6 & 0,000 & 0,05 & Valid \\
\hline 23 & FS7 & 0,000 & 0,05 & Valid \\
\hline 24 & PE1 & 0,000 & 0,05 & Valid \\
\hline 25 & PE2 & 0,000 & 0,05 & Valid \\
\hline 26 & PE3 & 0,000 & 0,05 & Valid \\
\hline 27 & PE4 & 0,000 & 0,05 & Valid \\
\hline 28 & PE5 & 0,000 & 0,05 & Valid \\
\hline
\end{tabular}

Sumber: Data Diolah (2020)

\section{Uji Reliabilitas}

Uji reliabilitas digunakan untuk pengujian untuk mengukur konsistensi seluruh pertanyaan terhadap kualitas data primer, dengan tujuan dalam penelitian ini. Adapun hasil uji reliabilitas dalam penelitian ini adalah sebagai berikut:

Tabel 2

Uji Reliabilitas

\begin{tabular}{|l|c|c|}
\hline \multicolumn{1}{|c|}{ Variabel } & Cronbach's Alpha & Keterangan \\
\hline Shopping Lifestyle & 0,773 & Reliabel \\
\hline Fahion Involvement & 0,837 & Sangat Reliabel \\
\hline Faktor Situasional & 0,864 & Sangat Reliabel \\
\hline Positive Emotion & 0,837 & Sangat Reliabel \\
\hline
\end{tabular}

Sumber: Data Diolah (2020)

Berdasarkan hasil uji reliabilitas pada tabel 2 diatas terlihat semua pernyataan dalam shopping lifestyle dinyatakan reliabel karena memiliki nilai $>0.60$, sedangkan semua pernyataan dalam fashion involvement, faktor situasional dan positive emotion dinyatakan sangat reliabel karena memiliki nilai $>0.81$.

\section{Analisis Diskriminan}

Berdasarkan nilai Box's M adalah 24,544 dengan nilai sig 0,708 $(>0,05)$ maka $\mathrm{HO}$ diterima. Dengan demikian, artinya $\mathrm{HO}$ diterima, sehingga varians kedua kelompok dalam penelitian ini yaitu pria dan wanita data identik/homogeny dari kriteria ini, ini artiya bahwa analisis diskriminan dapat dilakukan.

Selanjutnya yaitu menguji signifikan dari fungsi diskriminan dengan cara melihat nilai Wilk's Lambda dan tingkat signifikan chi square. 
Tabel 3

Wilks'Lambda

\begin{tabular}{|c|c|c|c|c|}
\hline Test of Fuction (s) & Wilks'Lambda & Chi-square & $\mathrm{df}$ & Sig \\
\hline 1 & 0,746 & 39,789 & 4 & 0,000 \\
\hline
\end{tabular}

Sumber: Data Diolah (2020)

Dari tabel 3 diatas diperoleh nilai wilk's lambda sebesar 0,746, maka dapat diartikan bahwa terdapat perbedaan antara kelompok pria dan wanita. Pada tabel diatas juga diperoleh nilai chi square sebesar 39,789 dengan tingkat

signifikan sebesar 0,000 $(<0,05)$. Berdasarkan hasil dari data tersebut bisa disimpulkan bahwa terdapat perbedaan antara kelompok pria dan wanita atau dapat dikatakan bahwa hipotesis 1 diterima.

Tabel 4

Eigenvalue

\begin{tabular}{|l|l|l|r|r|}
\hline & & & & \multicolumn{1}{|c|}{ Canonical } \\
\hline Fuction & Eigenvalue & \% of Variance & Cumulative \% & Correlation \\
\hline 1 & $1,740^{2}$ & 100,0 & 100,0 & 0,804 \\
\hline
\end{tabular}

a. First 1 canonical discriminant functions were used in the analysis

Sumber: Data Diolah (2020)

Dari tabel 4 diatas, diperoleh nilai canonical correlation sebesar 0,804 atau besarnya square canonical correlation bila dikuadratkan $(0,804 \times 0,804)=0,646416$ yang mengartikan bahwa $65 \%$ varians dari variabel shopping lifestyle, fashion involvement, faktor situasional, dan positive emotion dalam perbedaan Impulse buying antara kedua kelompok pria dan wanita dapat dijelaskan dari model analisis diskriminan yang dibentuk. Nilai canonical correlation sebesar 0,804 berarti berhubungan sangat tinggi karena mendekati angka 1
Berdasarkan tabel Canonical Discriminant Function Coefficients dapat disimpulkan bahwa ada tiga variabel yang membedakan Impulse buying antara kelompok pria dan wanita yaitu fashion involvement, faktor situasional dan positive emotion. Ada 2 indikator dari variabel fashion involvement yang membedakan Impulse buying antara kelompok pria dan wanita, yaitu tertarik untuk melakukan pembelian produk fashion di Tokopedia dengan nilai koefisien sebesar 0,637 dan selalu mengikuti trend fashion sepanjang masa dengan nilai koefisien sebesar -0,595.

Tabel 5

Canonical Discriminant Function Coefficients

\begin{tabular}{|l|r|}
\hline & Function \\
\hline FI5_Pembelian produk & 1 \\
\hline FI9_Trend Fashion & 0,637 \\
\hline FS7_Promosi & $-0,595$ \\
\hline PE5_Tidak Dapat Mengendalikan Diri & 0,660 \\
\hline (Constant) & 0,570 \\
\hline Unstandardized coefficients & $-3,557$ \\
\hline Sumber: Data Diolah (2020) & \\
\hline
\end{tabular}

Selanjutnya ada 1 indikator dari faktor situasional yang membedakan Impulse buying antara kelompok pria dan wanita yaitu tertarik dengan kegiatan promosi di Tokopedia dengan nilai koefisien sebesar 0,660 serta ada 1 indikator dari positive emotion yang membedakan Impulse buying antara kelompok pria dan wanita yaitu ketika mereka berbelanja 
di Tokopedia tidak dapat mengendalikan diri dengan nilai koefisien sebesar 0,570. Berdasarkan tabel diatas dapat diketahui bahwa indikator dari variabel faktor situasional mempunyai nilai yang tertinggi dibandingkan dengan pernyataan dari indikator variabel

Adapun persamaan model diskriminan dari hasil analisis dapat dinyatakan sebagai berikut: $Y=-3,557+0,637$ Pembelian Produk $-0,595$ Trend Fasion $+0,660$ Promosi $+0,570$ Tidak dapat mengendalikan dir

Tabel 6

Functions at Group Centroids

\begin{tabular}{|l|r|}
\hline \multirow{2}{*}{ Jenis Kelamin } & \multicolumn{2}{|c|}{ Function } \\
\cline { 2 - 2 } & \multicolumn{1}{|c|}{0,579} \\
\hline Wanita & $-0,579$ \\
\hline Pria & \multicolumn{2}{|c|}{. } \\
\hline
\end{tabular}

Unstandardized canonical discriminant

functions evaluated at group means

Sumber: Data Diolah (2020)

Dari tabel 6 dapat dilihat bahwa terdapat Group centroid yang merupakan nilai dari rata-rata pada diskriminan dari setiap pernyataan di dalam masing-masing kelompok. Group centroid untuk kelompok jenis kelamin wanita yaitu 0,579, sedangkan untuk kelompok jenis kelamin pria yaitu $-0,579$. Dapat dikatakan hal ini berarti bahwa secara rata-rata skor diskriminan kedua kelompok berbeda. Sehingga fungsi diskriminan dapat memberikan perbedaan baik pada kelompok pria atau wanita.

Secara keseluruhan model diskriminan yang terbentuk mempunyai tingkat validasi yang cukup tinggi yaitu sebesar $72,1 \%$ yang dapat dilihat pada tabel 7 dibawah ini:

Tabel 7

Cassidication Results

\begin{tabular}{|c|c|c|c|c|c|}
\hline & & \multirow[b]{2}{*}{ Jenis Kelamin } & \multicolumn{2}{|c|}{ Predicted Group Membership } & \multirow[b]{2}{*}{ Total } \\
\hline & & & Wanita & Pria & \\
\hline \multirow[t]{4}{*}{ Original } & Count & Wanita & 53 & 17 & 70 \\
\hline & & Pria & 22 & 48 & 70 \\
\hline & $\%$ & Wanita & 75,7 & 24,3 & 100,0 \\
\hline & & Pria & 31,4 & 68,6 & 100,0 \\
\hline \multirow[t]{4}{*}{ Cross-validated $^{\mathrm{b}}$} & Count & Wanita & 53 & 17 & 70 \\
\hline & & Pria & 22 & 48 & 70 \\
\hline & $\%$ & Wanita & 75,7 & 24,3 & 100,0 \\
\hline & & Pria & 31,4 & 68,6 & 100,0 \\
\hline
\end{tabular}

a. $72,1 \%$ of original grouped cases correctly classified

b. Cross validation is done only for those cases in the analysis in cross validation,

c. $72,1 \%$ of cross-validated grouped cases correctly classified

Sumber: Data Diolah (2020)

Dengan demikian dapat diartikan bahwa model diskriminan layak digunakan untuk analisis disriminan atau digunakan pada penelitian ini.

Berdasarkan hasil penelitian ini, membuktikan bahwa terdapat perbedaan antara pria dan wanita dalam Impulse buying. Dimana responden wanita kebanyakan berusia 17-21 tahun yang berstatus pelajar atau mahasiswa cendenrung melakukan Impulse buying dengan adanya faktor promo diskon, gratis ongkir, barang atau produk dengan kualitas harga yang bagus dan tertarik dengan iklan atau tampilan di aplikasi Tokopedia. 
Renanita (2017) yang menunjukan pembelian yang dilakukan secara online didorong oleh faktor-faktor emosi seperti emosi kosumen, rendahnya kontrol kognitif juga perilaku spontan konsumen. Sedangkan responden pria kebanyakan berusioa 22-26 tahun yang berstatus sebagai karyawan lebih cenderung melakukan Impulse buying dengan adanya faktor dari membeli sesuai kebutuhan, ini artinya pria akan melakukan pembelian Impulse buying ketika meraka melihat bahwa produk yang ditawarkan di Tokopedia memang sesuai dengan yang mereka butuhkan. Hal ini sesuai dengan penelitian Kusumowidagdo (2010)menyatakan bahwa gender berpengaruh terhadap perilaku belanja dimana pria merupakan pebelanja utilitarian (konsumen yang berfokus pada manfaat yang nyata ketika berbelanja) sedangkan wanita kebanyakan merupakan pebelanja hedonis (konsumen yang mengandalkan respon emosional ketika berbelanja).

Berdasarkan hasil penelitian ini, membuktikan bahwa adanya perbedaan anatara pria dan wanita dalam Impulse buying berdasarkan variabel Fahion Involvement, Faktor Situasional dan Positive Emotion. Pada variabel fashion involvement, yang membuat konsumen tertarik untuk melakukan pembelian Impulse buying karena mereka senang melakukan pembelian produk fashion dan karena mereka selalu mengikuti trend fashion sepanjang masa. Konsumen melakukan Impulse buying di Tokopedia karena produk fashion yang ditawarkan selalu mengikuti perkembangan mode fashion terbaru dengan kualitas dan bahan yang bagus serta harga yang sesuai dengan kantong para konsumen. Dari variabel faktor situasional yang membuat konsumen tertarik untuk melakukan Impulse buying karena adanya promosi yang dilakukan Tokopedia, dimana Tokopedia selalu mengadakan promosi diskon atau promosi dengan iklan yang ditayangkan melalui situs media sosial dan televisi hingga membuat konsumen tertarik untuk mengunjungin situs aplikasi Tokopedia. Selanjutnya pada variabel positive emotion, yang membuat konsumen melakukan Impulse buying karena saat berbelanja mereka tidak dapat mengendalikan diri. Konsumen pria yang tidak bisa menahan diri untuk melakukan Impulse buying apabila melihat produk yang ditawarkan di Tokopedia sesuai dengan kebutuhan mereka sedangkan wanita yang tidak bisa menahan diri untuk melakukan Impulse buying ketika Tokopedia melakukan promo seperti cashback, hadiah, dan juga flash sale artinya konsumen selalu mengikutin perkembangan fashion dan melihat produk yang sedang trend di aplikasi Tokopedia. Dari ketiga variabel tersebut yang paling membedakan Impulse buying antara pria dan wanita adalah variabel faktor situasional yaitu promosi di Tokopedia. Hal ini berarti bahwa konsumen terdorong untuk melakukan Impulse buying di Tokopedia karena promosi atau iklan berupa diskon harga, bonus pembelian dengan cashback serta gratis ongkir dengan minimal pembelian. Hasil Penelitian ini sesuai dengan penelitian Renanita (2017) dimana hasil penelitian menemukan bahwa wanita lebih impulsif dibandingkan pria. Hal ini dapat disebabkan oleh perbedaan shopping lifestyle antara pria dan wanita. Hasil penelitian ini juga memperkuat penelitian Rizki (2016) yang menunjukan bahwa terdapat perbedaan antara pria dan wanita dalam pembelian impulsif pada toko online, dari hasil tersebut juga diketahui bahwa variabel emosi positif adalah yang paling dominan membedakan dibandingkan variabel shopping lifestyle, fashion involvment dan faktor situasional

\section{Kesimpulan}

Terdapat perbedaan dalam Impulse buying antara pria dan wanita pada saat berbelanja di Tokopedia. Pria melakukan Impulse buying karena faktor membeli produk yang mereka butuhkan sedangkan wanita melakukan Impulse buying lebih karena faktor promo yang ditawarkan oleh Tokopedia. Variabel yang membedakan Impulse buying pria dan wanita adalah fashion infolvement dengan indikator yaitu tertarik untuk melakukan pembelian produk fashion di Tokopedia dan selalu mengikuti trend fashion sepanjang masa, Variabel faktor situasional dengan indikator yaitu tertarik dengan kegiatan promosi di Tokopedia dan postitive emotion dengan indikator yaitu ketika mereka berbelanja di Tokopedia tidak dapat mengendalikan diri. Sedangkan Variabel yang paling dominan dalam membedakan Impulse buying antara pria dan wanita adalah variabel faktor 
situasional yaitu tertarik dengan adanya kegiatan promosi. Artinya, pria dan wanita melakukan Impulse buying di Tokopedia karena adanya promosi yang Cashback, hadiah, dan juga flash sale

Hasil penelitian ini diharapkan dapat membantu dalam segala pihak yang bergeral atau berhubungan dengan e-commerce. Peneliti berharap secara khusus hasil penelitian ini dapat membantu pihak Tokopedia. Dalam hal Shopping Lifestyle, Tokopedia dapat mengikuti perkembangan gaya hidup atau cara orang dalam melakukan up to date pada perkembagan saat ini. Selain itu Tokopedia dapat meningkatkan Positive Emotion dengan cara memberikan rasa nyaman pada saat melakukan pembelian hingga konsumen merasakan kesenangan saat membeli. Hal-hal tersebut diharapkan dapat membatu Tokopedia dalam bersain dengan e-commerce lain pada era perkembangan saat ini berbelanja online menjadi pilihan penting bagi para konsumen.

\section{Daftar Pustaka}

Afandi, A. R., \& Hartati, S. (2019). Pembelian Impulsif pada Remaja Akhir Ditinjau dari Kontrol Diri. Gadjah Mada Journal of Psychology (GamaJoP). https://doi.org/10.22146/gamajop.4410 3

Andriyanto, D., Suyadi, I., \& Fanani, D. (2016). Pengaruh Fashion Involvement Dan Positive Emotion Terhadap Impulse Buying (Survey pada Warga Kelurahan Tulusrejo Kecamatan Lowokwaru Kota Malang). Jurnal Administrasi Bisnis S1 Universitas Brawijaya.

Ariva Sultana. (2016). Hubungan Self Control Dengan Fashion Involvement Pada Mahasiswa Fakultas Ekonomi Dan Bisnis Universitas Brawijaya. Skripsi.

Astari, L., \& Widagda K., I. (2014). Pengaruh Perbedaan Jenis Kelamin Dan Kontrol Diri Terhadap Keputusan Pembelian Impulsif Produk Parfum. E-Jurnal Manajemen Universitas Udayana.

Chan, T. K. H., Cheung, C. M. K., \& Lee, Z. W. Y. (2017). The state of online impulsebuying research: A literature analysis. Information and Management. https://doi.org/10.1016/j.im.2016.06.00 1
Chang, H. J., Yan, R. N., \& Eckman, M. (2014). Moderating effects of situational characteristics on impulse buying. International Journal of Retail and Distribution Management. https://doi.org/10.1108/IJRDM-04-20130074

Darma, L. A., \& Japarianto, E. (2014). Analisa Pengaruh Hedonic Shopping Value terhadap Impulse Buying dengan Shopping Lifestyle dan Positive Emotion sebagai Variabel Intervening pada Mall Ciputra World Surabaya. Jurnal Manajemen Pemasaran.

Dewi, N. (2015). Pengaruh Fashion Involvemet Dan Kecenderngan Hedonic Consumption Dengan Mediator Emosi Positif Terhadap Pembelian Impulsif Berorientasi Fashion (Survei Pada Pembeli Pakaian Di Mal Olympic Garden Kota Malang). Jurnal Administrasi Bisnis S1 Universitas Brawijaya, 26(2), 86284.

Diba, D. S. (2013). Peranan Kontrol Diri Terhadap Pembelian Impulsif Pada Remaja Berdasarkan Perbedaan Jenis Kelamin Di Samarinda. Journal of Chemical Information and Modeling.

Fauziyyah, A. N., \& Oktafani, F. (2018). Pengaruh Shopping Lifestyle Dan Fashion Involvement Terhadap Impulse Buying Behavior. JURISMA: Jurnal Riset Bisnis \& Manajemen, 8(1). https://doi.org/10.34010/jurisma.v8i1.9 94

Hair. (2010). Multivariate Data Analysis. Seventh Edition. Prentice Hall. Exploratory Data Analysis in Business and Economics. https://doi.org/10.1007/978-3-31901517-0_3

Hursepuny, C. V., \& Oktafani, F. (2018). Pengaruh Hedonic Shopping Motivation Dan Shopping Lifestyle Terhadap Impulse Buying Pada Konsumen Shopee Id. E-Proceeding of Management.

In'am, M., Suharyono, S., \& Yulianto, E. (2016). Analisis Faktor-Faktor Yang Berpengaruh Terhadap Pembelian Impulsif (Survei pada Pengunjung yang Melakukan Pembelian Impulsif di Distro 3Second Cabang Mall Olympic Garden Malang). Jurnal Administrasi Bisnis S1 Universitas 
Brawijaya.

Japarianto, E., \& Sugiharto, S. (2012). Pengaruh Shopping Life Style Dan Fashion Involvement Terhadap Impulse Buying Behavior Masyarakat High Income Surabaya. Jurnal Manajemen Pemasaran.

https://doi.org/10.9744/pemasaran.6.1. $32-41$

Kusumowidagdo, A. (2010). Pengaruh desain atmosfer toko terhadap perilaku belanja studi atas pengaruh gender terhadap respon pengunjung toko. International Research Journal of Business Studies.

Liantifa, M., \& Siswadhi, F. (2019). Shopping Lifestyle As A Mediation Variable In The Effect Of Hedonic Shopping Value On Buying Impulse In Online Shop. Jurnal Apresiasi Ekonomi. https://doi.org/10.31846/jae.v7i2.210

Limento, N. Y., \& Cahyadi, L. (2020). Analisis Pengaruh Brand Loyalty, Brand Association, Brand Awareness Dan Perceived Quality Terhadap Keputusan Pembelian. JCA of Economics, 01(02).

Malhotra, N. K. (2009). Riset Pemasaran, Edisi keempat, Jilid 1. Jakarta: PT Indeks.

Marianty, R. (2012). Pengaruh Keterlibatan Fashion Emosi Positif Dan Kecenderungan Konsumsi Hedonik Terhadap Pembelian Impulsif. Journal of Chemical Information and Modeling.

Maulana, A., . M., \& Novalia, N. (2019). The Effect of Shopping Life Style and Positive Emotion on Buying Impulse (Case Study of the Palembang City Hypermarket). Information Management and Business Review. https://doi.org/10.22610/imbr.v11i1.284 4

Mothersbaugh, D. L., \& Hawkins, D. I. (2016). Consumer Behavior: Building Marketing Strategy, Thirteenth Edition. Mc Graw Hill Education .

Natalie A., A., \& Japarianto, E. (2019). Analisis Pengaruh Fashion Involvement Terhadap Impulse Buying Melalui Hedonic Value Di H\&M Store Pakuwon Mall Surabaya. Jurnal Manajemen Pemasaran.

https://doi.org/10.9744/pemasaran.13.1 .40-46
Ningrum, E. C., \& Matulessy, A. (2018). Self image dan impulsive buying terhadap produk fashion pada dewasa awal. FENOMENA.

https://doi.org/10.30996/fn.v27i1.1483

Pramesti, N. Y., \& Iqbal, M. (2018). Analisis Perbedaa Antara Shopping Lifestyle Dan Status Consumption Pada Generasi X, Y , Z (Survei Tentang Hijab Fashion Pada Wanita Berhijab di Jakarta). Jurnal Administrasi Bisnis (JAB), 63(1), 90-99.

Purwanto, D., \& Wijaya, T. (2018). Pengaruh Gender, Promosi Penjualan dan Sifat atrealisme Terhadap Perilaku Impulse Buying Secara Online (Studi Kasus Pada Mahasiswa Fakultas Ekonomu Universitas Negeri Yogyakarta). Jurnal Manajemen Dan Bisnis Indonesia.

Renanita, T. (2017). Kecenderungan Pembelian Impulsif Online Ditinjau dari Penjelajahan Website Yang Bersifat Hedonis dan Jenis Kelamin pada Generasi Y. Indigenous: Jurnal Ilmiah Psikologi, 2(1), 1-6. https://doi.org/10.23917/indigenous.v1i 1.4457

Rizki, R. (2016). Analisis Perbedaan Keputusan Pembelian Implusif Di Toko Online Berdasarkan Jenis Kelamin, 53(9).

Setyningrum, F., Arifin, Z., \& Yulianto, E. (2016). Pengaruh Hedonic Motives Terhadap Shopping Lifestyle Dan Impulse Buying (Survei pada Konsumen Superindo Supermarket Yang Melakukan Impulse Buying). Jurnal Administrasi Bisnis S1 Universitas Brawijaya.

Sugiyono. (2017). MetodePenelitian Kuantitatif, Kualitatif dan R\&D. Bandung: PT Alfabet.

Tawas, H., \& Mandey, S. (2014). Merek Dan Fashion Involvement Pengaruhnya Terhadap Perilaku Impulse Buying Pada Konsumen. Jurnal Riset Ekonomi, Manajemen, Bisnis Dan Akuntansi. https://doi.org/10.35794/emba.v2i2.446 6

Tifferet, S., \& Herstein, R. (2012). Gender differences in brand commitment, impulse buying, and hedonic consumption. Journal of Product and Brand Management. https://doi.org/10.1108/1061042121122 
8793

Tirmizi, M. A., Kashif-Ur-Rehman, \& Saif, M. I. (2009). An empirical study of consumer impulse buying behavior in local markets. European Journal of Scientific Research.

Tulungen, C. E. (2013). Comparative Analysis of Impulse Buying Based on Gender Differences. Jurnal Riset Ekonomi, Manajemen, Bisnis Dan Akuntansi, 1(4), 1349-1357.

https://doi.org/10.35794/emba.v1i4.291 4

Widiartaka, W., \& Purnami, N. (2014). Pengaruh Lingkungan Toko Dan Faktor Situasional Terhadap Perilaku Pembelian Tak Terencana Pada Matahari Department Store Denpasar. E-Jurnal Manajemen Universitas Udayana.

Zhang, K. Z. K., Xu, H., Zhao, S., \& Yu, Y. (2018). Online reviews and impulse buying behavior: the role of browsing and impulsiveness. Internet Research. https://doi.org/10.1108/IntR-12-20160377 